\title{
Formation and temporal evolution of the Venetian Kaapvaal lithosphere
}

\author{
R.C. Hin, M.L.A. Morel, O. Nebel, G.R. Davies \\ Faculty of Earth and Life Sciences, Vrije Universiteit Amsterdam, The Netherlands
}

The South African Venetia kimberlite pipes are situated in the metamorphic crust of the Limpopo Mobile Belt. Seismic tomography (James et al., 2001) suggests that the metamorphic crust is underlain by mantle lithosphere similar to the Zimbabwe and Kaapvaal Cratons. Furthermore, $\mathrm{U} / \mathrm{Pb}$ studies on zircons from the Venetia region suggest crustal protolith ages as old as 3.65 Ga (e.g., Zeh et al., 2007), in close similarity to Archaean Cratons.

Xenoliths from the Venetia kimberlite pipes are investigated in order to establish if silica enrichment of the sub-continental lithospheric mantle (SCLM) beneath the Archaean Kaapvaal craton originated prior to kimberlite emplacement at 533 Ma. Notably, Venetia xenoliths were unaffected by the Karoo flood basalt event and Group II type kimberlite magmatism and diamond inclusion data argue for extreme major element depletion in the SCLM beneath Venetia (Viljoen et al., 1999). Venetian diamond inclusion trace element data (Stachel et al., 2004) and previous major and trace element studies on Venetian mantle xenoliths (Stiefenhofer et al., 1999; Barton and Gerya, 2003) suggest that cryptic (silicate melt dominated) metasomatism occurred. Rhenium depletion ages for 7 mantle xenoliths yield two age populations of $\sim 1.4 \mathrm{Ga}$ and $>2.5$ Ga (Carlson et al., 1999), apparently unrelated to the regional Limpopo tectono-magmatic event. Estimates of the time of diamond formation range from less than $50 \mathrm{Myr}$ prior to eruption to an older generation that formed at $\sim 2.5 \mathrm{Ga}$, with eclogitic inclusions formed at 2.05 Ga (Burgess et al., 2004; Richardson et al., 2006; Richardson and Shirey, 2008).

550 peridotite xenoliths were studied in the field; $55 \%$ harzburgites, $\quad 37 \%$ lherzolites and $8 \%$ dunites/pyroxenites, all were heavily altered. To avoid the effects of metasomatic events and severe alteration, 35 relatively fresh harzburgites were selected for a detailed petrological and geochemical study. Petrographically, three groups of xenoliths were recognised. Group I consists of $6 \mathrm{cpx}$-free garnet harzburgites. One has an equant coarse texture, the other five are porphyroblastic. Garnet compositions are sub-calcic and olivine has Mg\# of 91.7-93.4. Mineral major element data suggest that garnet, olivine and opx are in major element equilibrium, except for one sample that may have suffered from slight metasomatism by an asthenosphere-derived melt as suggested by variably $\mathrm{TiO}_{2}$ enriched garnet and opx
Mg\# from 90.8 to 93.4. Group II includes 14 spinel lherzolites of which 8 have coexisting garnet. They have equant coarse textures, although opx is sometimes lobate and garnets are often interlobate to vermicular forming (linear) clusters. Cpx $(<2 \%)$ often occurs as texturally equilibrated grains. Mineral chemistry is very homogeneous with olivine Mg\# of 92.2-92.7 and all minerals appear to be in major element equilibrium (Fig. 1). Group III includes 15 garnet lherzolites with porphyroblastic textures covering a range of compositions, reflected by olivine Mg\# of 88.7-92.3. About half of the samples contain $\sim 2 \%$ poikiloblastic cpx. Mineral major element data suggest that minerals in all but two samples are in major element equilibrium. Opx abundances among the three groups vary from $<10 \%$ in some group I samples to about $25 \%$, with most samples having $\sim 20 \%$ opx. This suggests that $\mathrm{SiO}_{2}$ enrichment of the SCLM had occurred prior to entrainment of Venetian mantle xenoliths at $\sim 533 \mathrm{Ma}$, although the enrichment seems less extreme than beneath the Kaapvaal Craton (e.g., Pearson and Wittig, in press).

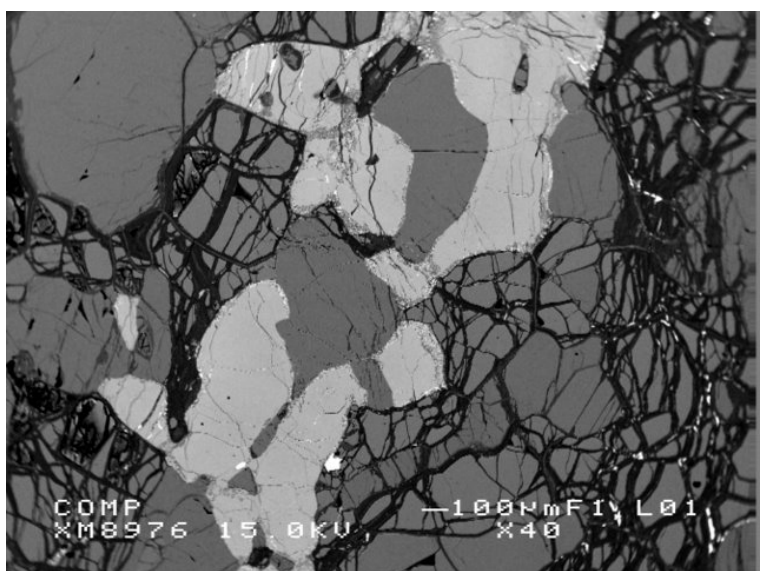

Fig. 1. Back scatter electron image of a garnet-bearing group II sample. Garnet (light grey reflection) is not fully texturally equilibrated and often occurs clustered having interlobate to vermicular textures.

Pressure and temperature calculations (mostly from groups I and III) range from $5.5 \mathrm{GPa}$ at $1270^{\circ} \mathrm{C}$ to 6.4 $\mathrm{GPa}$ at $1451^{\circ} \mathrm{C}$. The exceptions are an equant coarse garnet harzburgite $\left(5.2 \mathrm{GPa}\right.$ at $\left.1126^{\circ} \mathrm{C}\right)$ and two group II samples (lowest PT of $2.7 \mathrm{GPa}$ at $826^{\circ} \mathrm{C}$ ). All samples plot close to a $43 \mathrm{~mW} \mathrm{~m}^{-2}$ geotherm.

Following the work of Bernstein et al. (2007), olivine 
Mg\# suggest that melt percentages for group I samples vary from $\sim 28 \%$ to $\sim 53 \%$, whereas estimates for group II samples display a smaller range from $34 \%$ to $42 \%$ (Fig. 2). Group III samples have lower melt percentages between 21 and 38\% excluding the two samples with the lowest Mg\# (90.0 and 88.7) close to or lower than assumed fertile mantle, suggesting modification by metasomatism.

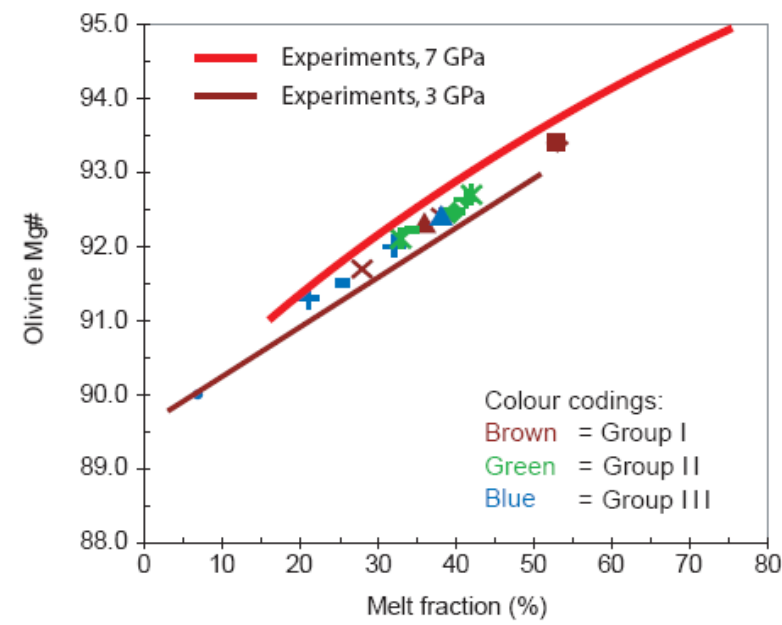

Fig. 2. Olivine Mg\# versus melt fraction. Venetia melt fractions vary from $\sim 21$ to $\sim 53 \%$, with the highest estimates for group I samples (brown symbols) and group III samples (blue symbols) generally on the lower side. Different symbol shapes refer to different samples (same in each figure). Distinction between high $(7 \mathrm{GPa})$ and low (3 GPa) pressure melting is not possible. (After Pearson and Wittig, in press.)

In situ LA-ICPMS on 8 samples reveal large heterogeneity, e.g., garnet $[\mathrm{La}]_{\mathrm{N}}$ varies from 0.05 to 1.9 and $[\mathrm{Lu}]_{\mathrm{N}}$ from 0.97 to 11.8. LREE in opx are also highly variable with $[\mathrm{La}]_{\mathrm{N}}$ between 0.03 and 2.7 . Distinction between the three groups for garnet trace elements is not as clear as for major element chemistry, while opx trace element compositions show no systematic variation. Garnet REE compositions vary from LREE depletion $\left([\mathrm{Ce} / \mathrm{Yb}]_{\mathrm{N}}=0.19-0.50\right)$ in group III to strongly sinusoidal patterns in group I, while group II samples are intermediate. Sinusoidal patterns can occur with tight peaks at $[\mathrm{Sm}]_{\mathrm{N}}$ or $[\mathrm{Eu}]_{\mathrm{N}} \sim 4.5$ or with wider peaks shifted to lighter REE compositions $\left([\mathrm{Ce}]_{\mathrm{N}}\right.$ or $[\mathrm{Pr}]_{\mathrm{N}}$ about 6.5 to 9.0$)$. The latter resemble fluid-dominated metasomatism (Stachel et al., 2004) in contrast to generally melt metasomatised Venetian mantle xenoliths (Stiefenhofer et al., 1999). Garnet diamond inclusions have dominantly sinusoidal $[\mathrm{REE}]_{\mathrm{N}}$ patterns (Stachel et al., 2004), but also vary considerably in composition. Whole rock HREE contents were reconstructed from garnet, opx and (if present) cpx trace element data and modal abundances and compared to simple melt depletion modelling following Hellebrand et al. (2002) (Fig. 3). Group I and II samples can be modelled by either $15 \%$ melting in the spinel field or combined 20\% garnet field melting followed by $\sim 15 \%$ spinel field melting. The reconstructed whole rock REE patterns do not distinguish between $\sim 15 \%$ spinel field melting alone and combined garnet + spinel field melting, but the total of $\sim 35 \%$ for the latter scenario closely resembles melt extraction estimates derived from olivine compositions. Group III samples require less melting (as low as $\sim 10 \%$ ), but again dominantly in the absence of garnet as suggested by their low HREE contents $\left([\mathrm{Lu}]_{\mathrm{N}}\right.$ in all samples varies from 0.8 to 0.05 ). The conclusion that $\sim 15 \%$ spinel field melting is required for all samples implies later subduction to transport samples back to garnet stability field depths.
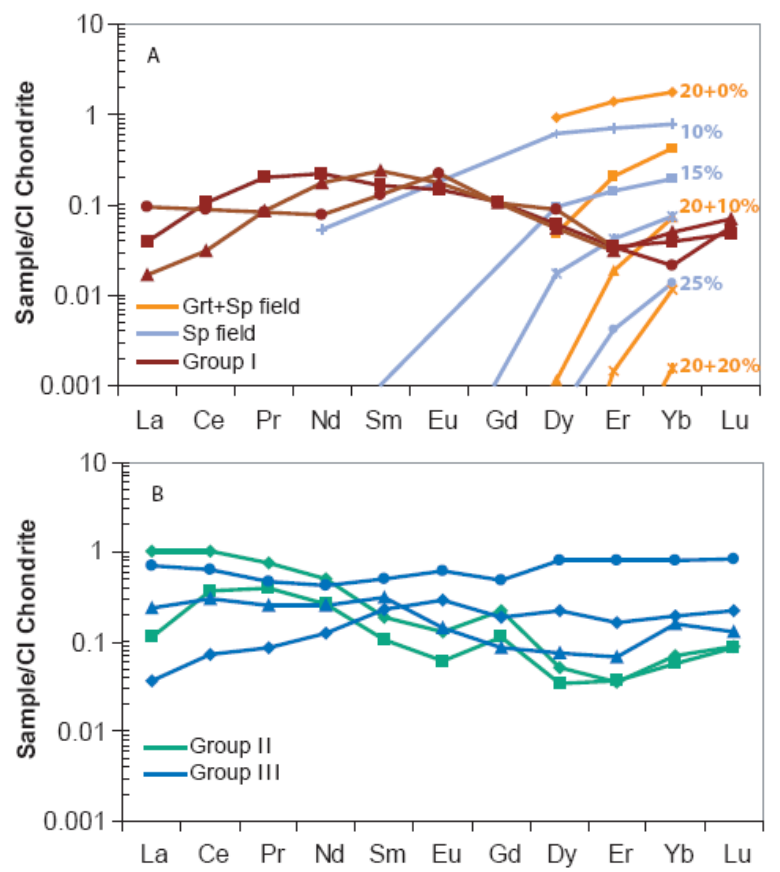

Fig. 3. Reconstructed whole rock $[R E E]_{N}$ patterns. Melting models for HREE concentrations are shown in (a) together with patterns for samples from group I. Patterns for samples from groups II and III are shown in (b). The low reconstructed whole rock $\mathrm{HREE}_{\mathrm{N}}$ concentrations for all samples indicate melting in the spinel field (minimum $15 \%$ for all but 1 sample).

REE partition coefficients $\left(K_{D}\right)$ calculated between garnet and opx suggest that only one garnet lherzolite (B00-45 from group III) of the 8 samples is within error of equilibrium $K_{D}$ from the literature. B00-45 was also the only sample with equilibrium gt/cpx $K_{D}$. Despite the inter-mineral trace element disequilibrium, hypothetical melts in equilibrium with garnet and cpx have been calculated from mineral trace element data and literature mineral/melt $K_{D}$. Constraints can be placed on the source of metasomatic agents by combining LILE, HFSE, LREE and HREE compositions of hypothetical melts and comparing these to true (natural) melt compositions. Calculated $[\mathrm{Nb} / \mathrm{Sr}]_{\mathrm{PM}}$ and $[\mathrm{Ce} / \mathrm{Yb}]_{\mathrm{PM}}$ in the hypothetical melts suggest that garnet formation is related to a mixture of metasomatism by hydrous fluids with elevated LREE/HREE (stage 1) followed by kimberlite-like metasomatism (stage 2; see Fig. 4). Calculated melts in equilibrium with cpx from (gt/cpx equilibrated) sample B00-45 plot within error of kimberlite and garnetderived melts. A second melt calculated in equilibrium 
with cpx from a group II sample plots close to the hydrous fluid field. This suggests cpx may have crystallised from hydrous fluids during stage 1 metasomatism. Alternatively, it is speculated that diffusive fractionation may have resulted in lower $\mathrm{Nb} / \mathrm{Sr}$ and higher $\mathrm{Ce} / \mathrm{Yb}$ than expected from partitioning behaviour.

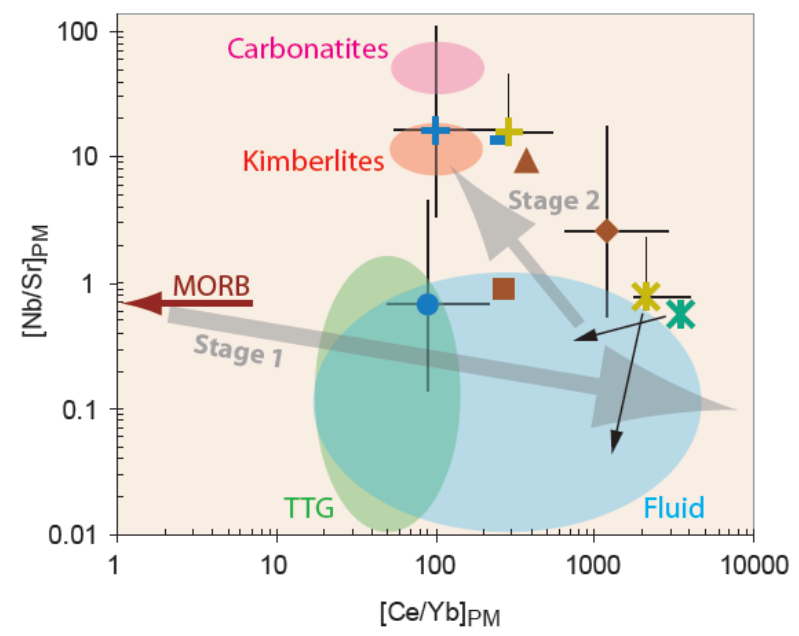

Fig. 4. Primitive mantle normalised $[\mathrm{Nb} / \mathrm{Sr}]$ versus [Ce/Yb] in melts. Nb (HFSE) and $\mathrm{Sr}$ (LILE) were chosen because of relatively large concentration differences in the melts from different tectonic environments. Shaded regions represent natural compositions for carbonatitic (pink), kimberlitic (red), subduction zone siliceous melts (e.g., TTG, melts in equilibrium with eclogite; green) and hydrous fluids (blue). Yellow symbols are calculated melts in equilibrium with cpx (plus symbol from a group III, asterisk from a group II sample), while green (group I), brown (group II) and blue (group III) symbols are hypothetical melts in equilibrium with garnet. Error bars on calculated melt compositions (not on all data points for clarity) relate to literature variation in mineral/melt partition coefficients, while the small black arrows show the magnitude and direction of the change in melt compositions calculated with mineral/fluid instead of mineral/melt $K_{D}$.

In conclusion, $\mathrm{SiO}_{2}$ enrichment of the Kaapvaal Craton occurred prior to $\sim 533 \mathrm{Ma}$. Venetian mantle xenoliths experienced on average $\sim 15 \%$ melting in the spinel stability field, implying later tectonic subduction to transport them to garnet stability fields. Metasomatism occurred in at least two stages, first by hydrous fluids and subsequently by kimberlite-like melts. From diamond inclusions it can be inferred that the first stage took place after subduction had transported the samples to garnet stability fields and that the hydrous fluid stage of metasomatism is likely to be related to diamond formation. Ongoing Nd-Hf mineral isotope data will be used to deduce the timing of the above events.

\section{References}

Barton Jr, J.M., Gerya, T.V., 2003. Mylonitization and decomposition of garnet: evidence for rapid deformation and entrainment of mantle garnetharzburgite by kimberlite magma, K1 pipe, Venetia Mine, South Africa. South African Journal of Geology 106, 231-246.

Bernstein, S., Kelemen, P.B., Hanghøj, K., 2007. Consistent olivine $\mathrm{Mg \#}$ in cratonic mantle reflects Archean mantle melting to the exhaustion of orthopyroxene. Geology 35, 459-462.

Burgess, R., Kiviets, G.B., Harris, J.W., 2004. Ar-Ar age determinations of eclogitic clinopyroxene and garnet inclusions in diamonds from the Venetia and Orapa kimberlites. Lithos 77, 113-124.

Carlson, R.W., Pearson, D.G., Boyd, F.R., Shirey, S.B., Irvine, G., Menzies, A.H., Gurney, J.J., 1999. Re-Os systematics of lithospheric peridotites: implications for lithosphere formation and preservation. In: Gurney, J.L., Gurney, J.J., Pascoe, M.D., Richardson, S.H. (Ed.), Proceedings of the $8^{\text {th }}$ International Kimberlite Conference, the J. Barry Hawthorne Volume, vol. 1, Red Roof Design cc, 99-108.

Hellebrand, E., Snow, J.E., Hoppe, P., Hofmann, A.W., 2002. Garnet-field melting and late-stage refertilization in 'residual' abyssal peridotites from the Central Indian Ridge. Journal of Petrology 43, 2305-2338

James, D.E., Fouch, M.J., VanDecar, J.C., Van der Lee, S., Kaapvaal Seismic Group, 2001. Tectospheric structure beneath southern Africa. Geophysical Research Letters 28, 2485-2488.

Pearson, D.G., Wittig, N., in press. Formation of Archaean continental lithosphere and its diamonds: the root of the problem. Journal of the Geological Society, London 165, 1-20.

Richardson, S.H., Harris., J.W., Pöml, P.F., 2006. Antiquity of harzburgitic diamonds from the Venetia kimberlite, Limpopo Belt, Kaapvaal craton. Goldschmidt Conference Abstracts, A531.

Richardson, S.H., Shirey, S.B., 2008. Continental mantle signature of Bushveld magmas and coeval diamonds. Nature 453, 910-913.

Stachel, T., Aulbach, S., Brey, G.P., Harris, J.W., Leos, I., Tappert, R., Viljoen, K.S., 2004. The trace element composition of silicate inclusions in diamonds: a review. Lithos 77, 1-19.

Stiefenhofer, J., Viljoen, K.S., Tainton, K.M., Dobbe, R., Hannweg, G.W., 1999. The petrology of a mantle xenoltih suite from Venetia, South Africa. In: Gurney, J.L., Gurney, J.J., Pascoe, M.D., Richardson, S.H. (Ed.), Proceedings of the $8^{\text {th }}$ International Kimberlite Conference, the J. Barry Hawthorne Volume, vol. 2, Red Roof Design cc, 836-845.

Viljoen, K.S., Phillips, D., Harris, J.W., Robinson, D.N., 1999. Mineral inclusions in diamonds from the Venetia kimberlites, Northern Province, South Africa. In: Gurney, J.L., Gurney, J.J., Pascoe, M.D., Richardson, S.H. (Ed.), Proceedings of the $8^{\text {th }}$ International Kimberlite Conference, the J. Barry Hawthorne Volume, vol. 2, Red Roof Design cc, 888895.

Zeh, A., Gerdes, A., Klemd, R., Barton Jr, J.M., 2007. Archaean to Proterozoic crustal evolution in the Central Zone of the Limpopo Belt (South AfricaBotswana): constraints from combined $\mathrm{U}-\mathrm{Pb}$ and $\mathrm{Lu}-$ $\mathrm{Hf}$ isotope analyses of zircon. Journal of Petrology $48,1605-1639$. 